\title{
Response of a salt-sensitive plant to processes of soil reclamation in two saline-sodic, coastal soils using drip irrigation with saline water
}

\author{
Xiaobin Li ${ }^{\mathrm{a}, \mathrm{b}}$, Yaohu Kang ${ }^{\mathrm{a}, *}$, Shuqin Wan ${ }^{\mathrm{a}}$, Xiulong Chen ${ }^{\mathrm{a}, \mathrm{b}}$, Shiping Liu ${ }^{\mathrm{a}}$, Jiachong Xu ${ }^{\mathrm{a}, \mathrm{b}}$ \\ ${ }^{a}$ Key Laboratory of Water Cycle and Related Land Surface Processes, Institute of Geographic Sciences and Natural Resources Research, Chinese Academy of \\ Sciences, Beijing 100101, China \\ ${ }^{\mathrm{b}}$ University of Chinese Academy of Sciences, Beijing 100101, China
}

\section{A R T I C L E I N F O}

\section{Article history:}

Received 19 July 2015

Received in revised form 21 October 2015

Accepted 29 October 2015

Available online 11 November 2015

\section{Keywords:}

Saline soil

Soil properties

Irrigation water salinity

Chinese rose

Management

\begin{abstract}
A B S T R A C T
The aim of this study was to evaluate the impact of soil types and properties on coastal saline soil reclamation and the response of plant growth to the reclamation processes in two soils. Two very heavy coastal saline soils were reclaimed in a three-year trial using drip irrigation with saline water. Chinese roses (Rosa chinensis) were planted, and soil indexes, growth characters, ion absorption and dry matter production were determined. Our results showed that significant salt leaching occurred in both soils, and the effect during the early period of reclamation was better in sandy loam than silt soil. There were higher emergence and survival rates of plants in sandy loam soil due to the rapid reclamation process, while plant growth and dry mass were greater in silt soil due to good fertilizer and water conservation. Most roots were present in the $0-20-\mathrm{cm}$ profile in both soils, but the fine root length value in silt soil was relatively high. These results indicate that water and nutrient management differed in the two soils. During soil reclamation, more attention should be paid to nutrient supply and maintaining soil moisture in sandy loam and to rapidly establishing suitable soil root-zone environments for plant emergence in silt soil.
\end{abstract}

(c) 2015 Elsevier B.V. All rights reserved.

\section{Introduction}

Saline soils are an important soil resource in the world, and coastal saline soil is one of the main types. In China, there is a large region of coastal saline land bordering the Pacific Ocean, including $10,000 \mathrm{~km}^{2}$ along the $6000 \mathrm{~km}$ of coastline extending from Jiangsu Province to Liaoning Province (Yu and Chen, 1999). Sandy loam and silt soils are the main soil types in this coastal saline region. The soils in these coastal areas are strongly affected by salinisation and sodification. They are characterized by high $\mathrm{EC}_{\mathrm{e}}$ (electrical conductivity of saturated paste extracts), SAR (sodium adsorption rate of saturated paste extracts) and chloride $\left(\mathrm{Cl}^{-}\right)$content, often related to their heavy texture. Plant growth is significantly affected via several mechanisms including sodium $\left(\mathrm{Na}^{+}\right)$or chloride toxicity, competition for uptake of other cations and osmotic effects on water uptake or interference with uptake of nutrients (Grewal,

\footnotetext{
* Corresponding author at: Key Laboratory of Water Cycle and Related Land Surface Processes, Institute of Geographic Sciences and Natural Resources Research, Chinese Academy of Sciences, 11 A Datun Road, Anwai, Beijing 100101, China. Fax: +8610 64856516

E-mail address: kangyh@igsnrr.ac.cn (Y. Kang).
}

2010; Naidu and Rengasamy, 1993; Rengasamy et al., 2003). Especially in fine-textured soils (silt), high SAR and the salinity problem have a marked detrimental effect on soil structure; and saline-sodic soils can slake, disperse and swell and further result in a decrease in water and air movement, plant-available water, root penetration, seedling growth and plant establishment (Akhter et al., 2004; Oster et al., 1999; Sumner, 1993). With the rapid industrialization and urbanization in coastal regions, there is an urgent need for reclamation of saline soils to meet the increasing demand for ecological construction.

The limited fresh water is one major factor restricting ecological construction in coastal regions. Many approaches including engineering, chemical and biological methods to reclaim saline soils have not yielded desirable results due to water limitations (Li et al., 2015). Non-conventional water resources such as saline water, brackish groundwater and treated wastewater are alternatives to fresh water (Rhoades et al., 1988). Saline water has been successfully used for irrigating crops and other plants (Crescimanno and Garofalo, 2006; Darvishi and Dadnia, 2012; Hadi and Raijadhav, 2007; Niu et al., 2011, 2012, 2013; Ozrad et al., 1972; Sa et al., 2013). However, most previous research on saline water irrigation has been based either on non-saline soils or using crops and salttolerant plants - there is a dearth of information on very heavy 
Table 1

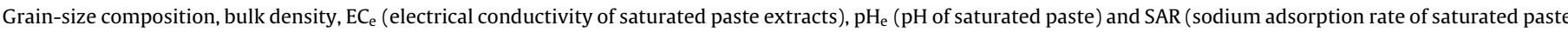
extracts) in both initial soils.

\begin{tabular}{|c|c|c|c|c|c|c|c|c|c|}
\hline \multirow[t]{2}{*}{ Site } & \multirow[t]{2}{*}{ Soil depth $(\mathrm{cm})$} & \multicolumn{3}{|c|}{ Grain-size composition (\%) } & \multirow[t]{2}{*}{ Soil texture class (USDA) } & \multirow[t]{2}{*}{ Bulk density $\left(\mathrm{g} / \mathrm{cm}^{3}\right)$} & \multirow[t]{2}{*}{$\mathrm{EC}_{\mathrm{e}}(\mathrm{dS} / \mathrm{m})$} & \multirow[t]{2}{*}{$\mathrm{pH}_{\mathrm{e}}$} & \multirow[t]{2}{*}{$\operatorname{SAR}(\mathrm{mmol} / \mathrm{L})^{0.5}$} \\
\hline & & $<0.002 \mathrm{~mm}$ & $0.002-0.05 \mathrm{~mm}$ & $0.05-2 \mathrm{~mm}$ & & & & & \\
\hline Eco-city & $0-120$ & 0.70 & 80.14 & 19.16 & Silt & 1.60 & 29.71 & 8.02 & 57.50 \\
\hline Industrial area & $0-120$ & 0.42 & 42.85 & 56.73 & Sandy loam & 1.56 & 26.33 & 7.84 & 50.17 \\
\hline
\end{tabular}

saline soils with high $\mathrm{EC}_{e}$ and SAR and landscape plants sensitive to salt - thus this is a problem that ecological construction must confront during reclamation of saline soils using saline water irrigation. Our group has developed a rapid and sustainable approach for vegetation landscape construction in coastal saline soils and this approach has proved effective in reclamation of very heavy saline soil (Li et al., 2015). The method relies on soil treatment and drip irrigation. Soils are tilled and treated with a gravel-sand layer and saline water is used to irrigate salt-sensitive plants.

However, the soil reclamation processes differ with soil hydraulic conductivities and can produce different soil physical and chemical properties during the reclamation processes in different soils, further affecting plant growth. The effects of soil properties on plants may be proportionally greater and result in different threshold values for saline water irrigation. In the present study, Chinese rose (Rosa chinensis), a conventional landscape flower plant and confirmed as sensitive to soil salinity, were planted in coastal regions with two very heavy saline soils (sandy loam and silt soils), and received water at five levels of salinity using drip irrigation. The primary objective of the work was to determine the effects of different soil types and properties on the soil reclamation processes using the proposed method and the response of plant growth to the reclamation processes in the two soils. The results will be useful in improving the method of reclamation of different saline soils for sensitive plants using drip irrigation with saline water.

\section{Materials and methods}

\subsection{Site description}

Field experiments were conducted in the International Eco-City $\left(39^{\circ} 20^{\prime} \mathrm{N}, 118^{\circ} 54^{\prime} \mathrm{E}\right)$ and the Industrial Zone $\left(39^{\circ} 03^{\prime} \mathrm{N}, 118^{\circ} 48^{\prime} \mathrm{E}\right)$, respectively, during 2012-2014. Both areas were located in Caofeidian District in the south of Tangshan city, east China, and north of Bohai Gulf which borders the Pacific Ocean (Fig. 1). The study areas are characterized by a temperate semi-humid monsoon climate with annual precipitation of approximately $550 \mathrm{~mm}$, with most rainfall during June-September.

According to Wang et al. (1993), the saline soils of the study areas are two typical coastal saline soils developed from beach mud, with the main ions being chloride and $\mathrm{Na}^{+}$. The $\mathrm{EC}_{\mathrm{e}}$ and SAR of the nonreclaimed saline soils at a depth of $100 \mathrm{~cm}$ were $26.0-30.0 \mathrm{dS} \mathrm{m}^{-1}$ and $50.0-59.0\left(\mathrm{mmol} \mathrm{L}^{-1}\right)^{0.5}$, respectively. The bulk density was in the range of $1.70-1.85 \mathrm{~g} \mathrm{~cm}^{-3}$, and reduced to $1.50-1.65 \mathrm{~g} \mathrm{~cm}^{-3}$ after soil tillage, excavation and backfilling (Table 1 ). The soils were silt in the International Eco-City and sandy loam in the Industrial Zone based on soil classification standard of USDA. In particular, the saline silt had characteristics of sticky texture structure and poor ventilation and permeability. The soil texture, soil bulk density, $\mathrm{EC}_{\mathrm{e}}$, $\mathrm{pH}_{\mathrm{e}}$ and SAR in the two experiment sites are shown in Table 1.

The surroundings of the both experimental sites are all wasteland due to the high salt content in soil and there are no factory buildings and residential areas, so no external environment factors from people exist which may influence the experiment.

\subsection{Plot layout and management}

In order to extend the application of the proposed reclamation method and display its popularization, a salt-sensitive plant (Chinese rose, $R$. chinensis) was selected. The successful survival of the salt-sensitive plant could confirm that the reclamation method is more effective in salt tolerant plants survival due to their higher salt tolerance. In addition, Chinese rose (R. chinensis), as an important shrubs flower in the coastal ecology landscape construction, has been widely applied in garden and road greening. Its successful application in reclamation of coastal saline lands could enhance the landscape reconstruction of the area.
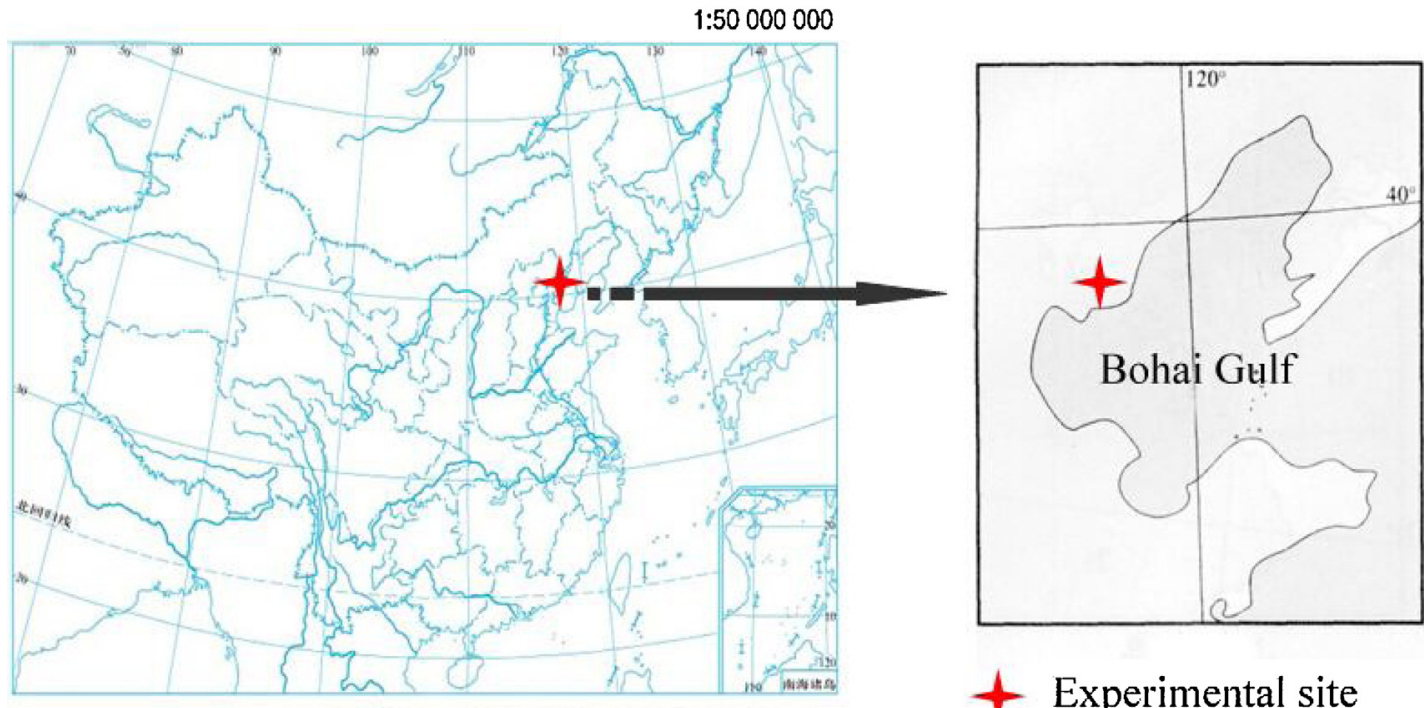

Experimental site

Fig. 1. The location of experimental site. 
Table 2

Ionic composition of irrigation water in the two soils.

\begin{tabular}{|c|c|c|c|c|c|c|c|c|}
\hline \multirow[t]{2}{*}{ Soil types } & \multirow[t]{2}{*}{$\mathrm{EC}_{\mathrm{iw}}(\mathrm{dS} / \mathrm{m})$} & \multicolumn{5}{|c|}{ Ionic concentration (mmol/L) } & \multirow[t]{2}{*}{$\mathrm{pH}_{\mathrm{e}}$} & \multirow[t]{2}{*}{$\operatorname{SAR}(\mathrm{mmol} / \mathrm{L})^{0.5}$} \\
\hline & & $\mathrm{Na}^{+}$ & $\mathrm{K}^{+}$ & $\mathrm{Ca}^{2+}$ & $\mathrm{Mg}^{2+}$ & $\mathrm{SO}_{4}^{2-}$ & & \\
\hline \multirow[t]{5}{*}{ Silt soil } & 0.8 & 6.38 & 0.16 & 1.45 & 0.45 & 0.29 & 8.55 & 4.63 \\
\hline & 3.1 & 24.40 & 0.51 & 2.94 & 2.32 & 1.58 & 8.52 & 10.64 \\
\hline & 4.7 & 36.46 & 0.74 & 3.66 & 3.79 & 2.46 & 8.40 & 13.35 \\
\hline & 6.3 & 47.82 & 0.95 & 4.04 & 5.27 & 3.37 & 8.37 & 15.68 \\
\hline & 7.8 & 62.84 & 1.24 & 4.55 & 7.15 & 4.34 & 8.05 & 18.37 \\
\hline \multirow[t]{5}{*}{ Sandy loam soil } & 0.8 & 11.88 & 0.35 & 1.35 & 0.41 & 0.17 & 8.92 & 8.95 \\
\hline & 3.1 & 25.07 & 0.52 & 2.50 & 2.10 & 2.51 & 8.67 & 11.69 \\
\hline & 4.7 & 35.72 & 0.74 & 3.72 & 3.39 & 4.22 & 8.66 & 13.39 \\
\hline & 6.3 & 48.61 & 1.04 & 3.89 & 5.39 & 6.21 & 8.59 & 15.96 \\
\hline & 7.8 & 59.79 & 1.25 & 5.46 & 6.68 & 8.13 & 8.50 & 17.16 \\
\hline
\end{tabular}

$\mathrm{EC}_{\mathrm{iw}}$-irrigation water electrical conductivity; SAR-sodium adsorption ratio.

The soil reclamation process included two steps. The first step was soil treatments. The soil treatments mainly included four stages: soil removal, gravel-sand layer laying, soil backfilling, and land leveling and vegetation planting. A depth of $100 \mathrm{~cm}$ of soil was removed and a $15-\mathrm{cm}$ thick gravel layer was laid in the bottom and then covered with a 5-cm thick layer of sand-with native soil placed back above the sand. The native silt saline soils were placed back in 30-cm layers and a rotary tiller was used to break soil aggregates between two layers to increase soil infiltration, while the rotary tiller was only used in the soil surface for sandy loam soil.

The second step was drip-irrigation. Five treatments with EC of irrigation water $\left(\mathrm{EC}_{\mathrm{iw}}\right)$ of $0.8,3.1,4.7,6.3$ and $7.8 \mathrm{dS} \mathrm{m}^{-1}$ were designed during the experiment, with saline water composed by mixing fresh well-water and highly saline shallow-groundwater in different proportions. The ionic composition of irrigation water is shown in Table 2. Each treatment was replicated three times in 15 plots and laid out permanently following a completely randomized block design.

Each treatment had a separate gravity drip-irrigation system consisting of a 200 - $\mathrm{L}$ tank installed $0.8 \mathrm{~m}$ above the ground to contain irrigation water. Drip tubes were placed in position at $0.05 \mathrm{~cm}$ from rose plants. One vacuum gauge tensiometer (WST-1, China) was installed $0.20 \mathrm{~m}$ directly underneath one emitter located in the center of the plot for each treatment. The tensiometer was observed twice daily (at 8:00 and 18:00 h), and irrigation was applied when the tensiometer reading exceeded the target soil matric potential (SMP) value. Based on the experimental results of Sun et al. (2012a; 2013), the SMP threshold was set at $-5 \mathrm{kPa}$ when the roses were transplanted, and $-10 \mathrm{kPa}$ after a growing season ended. For sandy loam soil, $-15 \mathrm{kPa}$ after October 2013 and then $-10 \mathrm{kPa}$ in 2014 were set considering the rapid salt leaching.

The drip-irrigation time was divided into two stages. The first stage was enhanced salt leaching and a period of irrigation for rose survival using freshwater. This stage used the same gravity dripirrigation system. The water head was located $0.5 \mathrm{~m}$ above the soil surface and was controlled by a bucket in which a float had been installed. Two drip tubes were placed at $30 \mathrm{~cm}$ distance between two closed rows of rose transplants and the distance between emitters was 20 and $30 \mathrm{~cm}$ in sandy loam and silt soil, respectively. Immediately after transplanting the rose seedlings in June 2012, freshwater was first applied to reduce the levels of soil salinity within the $0-10 \mathrm{~cm}$ soil layer. After that, the transplants were still establishing, so if SMP fell below $-5 \mathrm{kPa}$ then all the treatments were uniformly irrigated to maintain SMP at $-5 \mathrm{kPa}$, until all rose plants had successfully established in the soil.

The second stage was normal water-salt regulation using saline water. Irrigation started based on SMP. Water treatments based on different $\mathrm{EC}_{\mathrm{iw}}$ were initiated in July 2012. The treatments were connected to individual gravity drip-irrigation systems, which irri- gated the plants from 200-L tank containing irrigation water. The amount of water for each irrigation event of all treatments was $6 \mathrm{~mm}$ when SMP reached the threshold value. The drip tubes were reduced to one per plant row.

During 16-19 November 2012 and 27-30 November 2013, $24 \mathrm{~mm}$ of freshwater irrigation was applied to each treatment and then irrigation was terminated until April due to the onset of winter. During 1-4 April 2013 and 7-10 April 2014, $24 \mathrm{~mm}$ of freshwater irrigation was applied to each treatment to provide a suitable soil moisture environment for plant sprouting in spring.

During the experiment, urea, phosphoric acid and potassium dihydrogen phosphate were added into the fertilizer tank and dissolved in water so that the fertilizer was applied with the irrigation water. The same amount of fertilizer was applied for the five treatments. Rose plants were pruned in early December of each year, and were cut to uniform height for the five treatments. In winter of 2012, the plot was fenced with bamboo sticks, and covered with a protective cloth, due to the poor ability of these plants to endure cold in the first year. Other field management included weeding and pest control as used for conventional management of the landscape.

\subsection{Observation and measurements}

The number of surviving plants was counted monthly to calculate the survival rate of rose plants in 2012-2014, and the emergence rate was counted during March-April every year. The height and stem diameter were measured in 2012 and 2013. The total biomass (fresh and dry weights) of plants (one plant per replicate) was measured at the end of 2013.

Soil cores were obtained from each plot using an auger $(2.0 \mathrm{~cm}$ diameter, $15 \mathrm{~cm}$ high) in June, July and October 2012; March and November 2013; and March 2014. The samples were obtained at 0 , 10,20 and $30 \mathrm{~cm}$ from the emitters and all sample depths were the same: 0-10, 10-20, 20-30, 30-40, 40-60, 60-80 and 80-100 cm. The three replicate soil samples were mixed into one sample per treatment.

All soil samples were air-dried and passed through a 1-mm sieve. Soluble salt estimates, soluble cations content and soil $\mathrm{pH}_{\mathrm{e}}$ were determined in saturated paste extracts (Van Reeuvijk, 2002). The EC and $\mathrm{pH}_{\mathrm{e}}$ were determined using a conductivity meter (DDS-11A, REX, Shanghai) and a pHe meter (PHS-3C, REX), respectively. Soluble cations including calcium $\left(\mathrm{Ca}^{2+}\right)$, magnesium $\left(\mathrm{Mg}^{2+}\right)$, $\mathrm{Na}^{+}$, potassium $\left(\mathrm{K}^{+}\right)$and sulfate were measured with inductively coupled plasma optical emission spectrometry (ICP-OES) (Optima $5300 \mathrm{DV}, \mathrm{USA}$ ). Average $\mathrm{EC}_{\mathrm{e}}$ values within the whole soil profile or the root zone (identified as in soil about $40 \mathrm{~cm}$ horizontal to the center of two rows at a depth of $0-40 \mathrm{~cm}$ ) were integrated to account for both spatial and temporal variations. The average values of $\mathrm{EC}_{\mathrm{e}}$ in the soil profile was calculated as described in Li et al. (2015), 

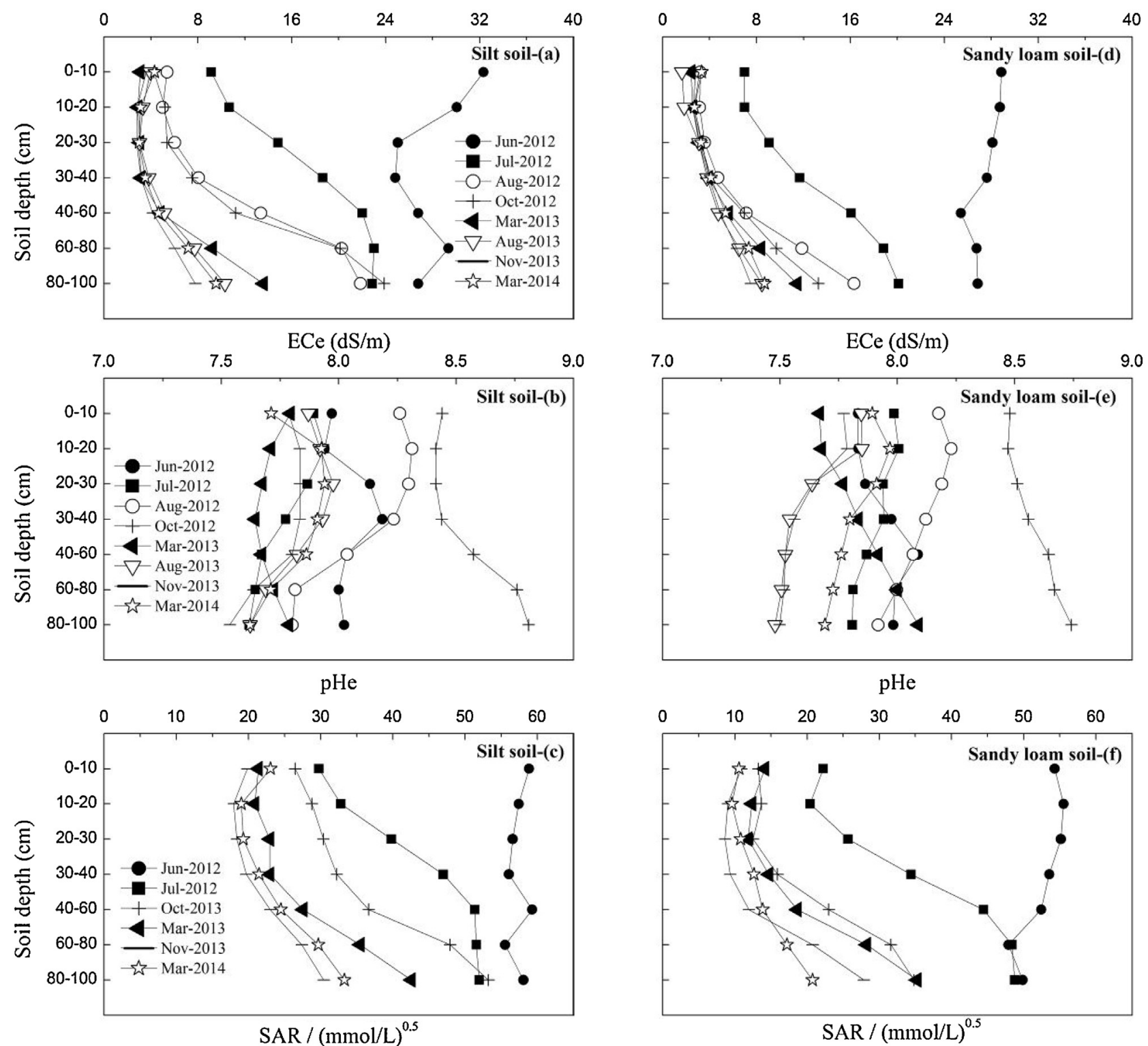

Fig. 2. The vertical distribution of average $\mathrm{EC}_{\mathrm{e}}, \mathrm{pH}_{\mathrm{e}}$ and $\mathrm{SAR}$ in both soils during the experimental periods.

Table 3

The plant height and stem diameter of Chinese rose at different irrigation water quality $\left(\mathrm{EC}_{\mathrm{iw}}\right)$ in the two soils from 2012 to 2013.

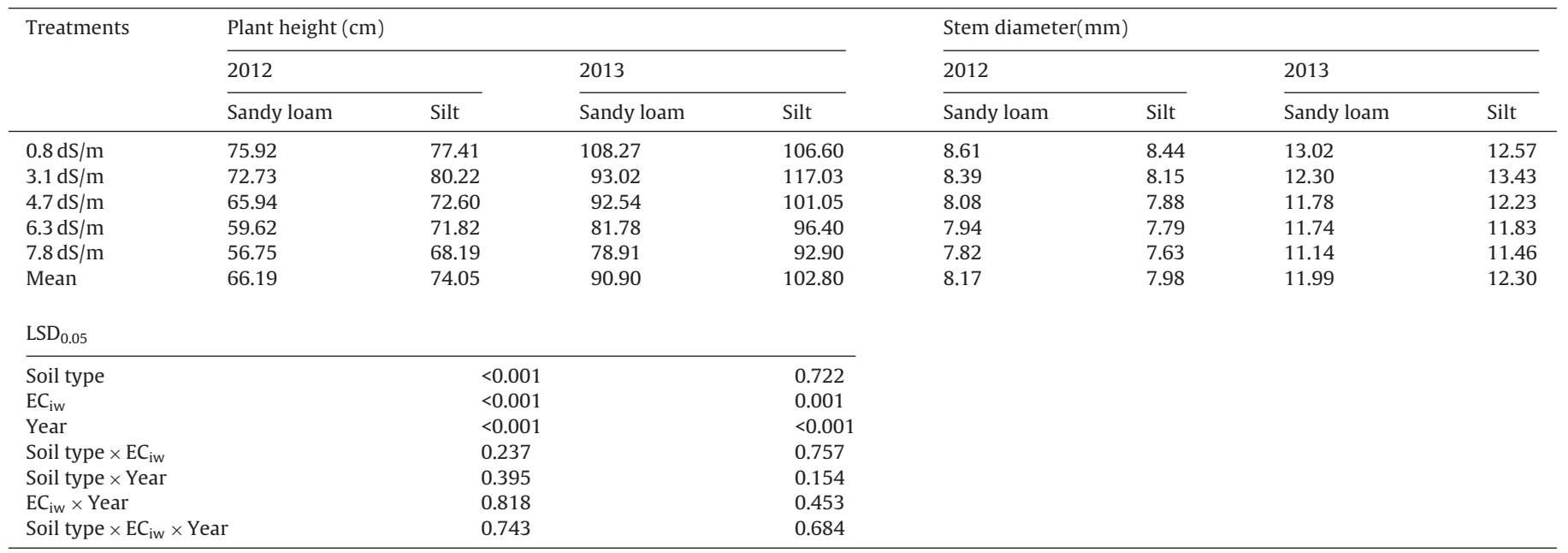


and the change of soil $\mathrm{EC}_{\mathrm{e}}\left(\Delta \mathrm{EC}_{\mathrm{e}}\right)$ in a period was calculated as follows:

$\Delta \mathrm{EC}_{\mathrm{e}}=\mathrm{EC}_{\mathrm{c}}(i)-\mathrm{EC}_{\mathrm{e}}(j)$

where $\Delta \mathrm{EC}_{\mathrm{e}}$ is in $\mathrm{dS} \mathrm{m}^{-1} ; \mathrm{EC}_{\mathrm{e}}(i)$ and $\mathrm{EC}_{\mathrm{e}}(j)$ are the soil $\mathrm{EC}_{\mathrm{e}}$ at the time of $i$ and $j$, respectively.

SAR of the saturated paste extract was calculated as follows:

SAR $=\frac{\left[\mathrm{Na}^{+}\right]}{\left(\left[\mathrm{Ca}^{2+}\right]+\left[\mathrm{Mg}^{2+}\right]\right)^{0.5}}$

where the concentration of each cation is in $\mathrm{mmol} \mathrm{L}^{-1}$.

At the end of 2013, plants (one plant per replicate) were destructively harvested and divided into leaves, stems and roots. After drying in a ventilated oven at $70^{\circ} \mathrm{C}$ for $48 \mathrm{~h}$, dry weight of each organ was determined. Each sample of plant leaves was ground in a mill (Retsch MM200, Retsch, Germany) to pass a 0.2-mm mesh. The oven-dried samples of leaves were digested in concentrated nitric acid at $130^{\circ} \mathrm{C}$ for elemental analysis using ICP-OES (Optima 5300DV) and a UV-vis spectrophotometer (HACH DR5000, USA).

The water production efficiency (WPE, $\mathrm{g} \mathrm{m}^{2} \mathrm{~mm}^{-1}$ ) was calculated as follows:

$\mathrm{WPE}=\mathrm{DM} / \mathrm{S} / \mathrm{SWID}$

where DM is the average dry mass per treatment $(\mathrm{g})$; $\mathrm{S}$ is the plot area $\left(\mathrm{m}^{2}\right)$; SWID is the saline water irrigation depth corresponding to the dry mass (mm).

A standard plant was chosen in each replicate, and root distribution was observed by taking soil samples to a depth of $50 \mathrm{~cm}$ in $10-\mathrm{cm}$ increments in a square of $30 \mathrm{~cm} \times 30 \mathrm{~cm}$ using the plant as center. Roots were divided into coarse and fine (diameter $<2 \mathrm{~mm}$ ) roots when root length was counted. Root distribution coefficient ( $\beta$, dimensionless) was obtained using the following equation:

$Y=1-\beta^{d}$

where $Y$ is the cumulative root fraction (\%) from the soil surface to depth $d(\mathrm{~cm})$ and was fitted to the data for each excavation.

\subsection{Statistical analyses}

All data were recorded and classified in Microsoft Office Excel 2007. Analyses of variance (ANOVA) were carried out using SPSS 16.0 statistical software (SPSS Inc., IL, USA). Spatial distributions of salinity indices in a surface made by distance from the emitters $(30 \mathrm{~cm}$ ) and depth of $100 \mathrm{~cm}$ were created using Origin 8.0 (Origin Lab Inc., MA, USA).

\section{Results}

\subsection{Soil properties}

The vertical distribution of the average $\mathrm{EC}_{\mathrm{e}}, \mathrm{pH}_{\mathrm{e}}$ and SAR of the five treatments in both soils during the soil reclamation processes, and the initial values in the soil profile are shown in Fig. 2. For the two non-reclaimed soils before rose transplanting, the $\mathrm{EC}_{\mathrm{e}}, \mathrm{pH}_{\mathrm{e}}$ and SAR values in $0-100 \mathrm{~cm}$ soil profiles were $24.0-32.0 \mathrm{dS} \mathrm{m}^{-1}$, 7.75-8.25 and 50.0-60.0 ( $\left.\mathrm{mmol} \mathrm{L}^{-1}\right)^{0.5}$ (June 2012), respectively, and no trends were found with soil depth. During the reclamation of saline soil using drip irrigation with saline water, the $\mathrm{EC}_{\mathrm{e}}$ and SAR values decreased with irrigation time and increased with soil depth (Fig. 2a, c, d and f), while the $\mathrm{pH}_{\mathrm{e}}$ values first increased to a range of $8.5-9.0$ and then decreased to $7.5-8.0$ (Fig. $2 \mathrm{~b}$ and e). In the period of enhanced salt leaching and irrigation for rose survival, significant decreases of $\mathrm{EC}_{\mathrm{e}}$ and SAR occurred in $0-40 \mathrm{~cm}$ soil profiles. After that, the $\mathrm{EC}_{\mathrm{e}}$ and $\mathrm{SAR}$ values were in the range of $0-4.0 \mathrm{dS} \mathrm{m}^{-1}$ and $8.0-15\left(\mathrm{mmol} \mathrm{L}^{-1}\right)^{0.5}$, respectively, for sandy loam soil in the $0-40 \mathrm{~cm}$ profile (Fig. $2 \mathrm{~d}$ and f), and $3-8 \mathrm{dS} \mathrm{m}^{-1}$ and 15-30 ( $\left.\mathrm{mmol} \mathrm{L}^{-1}\right)^{0.5}$ for silt soil (Fig. 2a and c).

The variations of average values of $\mathrm{EC}_{\mathrm{e}}, \mathrm{pH}_{\mathrm{e}}$ and SAR in $0-20$, $20-40$ and $0-100 \mathrm{~cm}$ profiles during reclamation in both soils are shown in Fig. 3. There were significant decreases in $\mathrm{EC}_{\mathrm{e}}$ and SAR in 2012 in all three profiles of both soils (Fig. 3a-1, a-3; b-1, b-3; and c-1, c-3), while $\mathrm{EC}_{\mathrm{e}}$ tended to be stable in 2013 and SAR still decreased. A better salt leaching effect occurred in sandy loam than silt soil in the three soil profiles in 2012 and in $0-20 \mathrm{~cm}$ in 2013, and there was no significant difference in $\mathrm{EC}_{\mathrm{e}}$ in $20-40$ and $0-100 \mathrm{~cm}$ in 2013 and 2014. In March 2014, the average $\mathrm{EC}_{\mathrm{e}}$ of the five treatment values in silt soil were $3.71,3.26$ and $5.66 \mathrm{dS} \mathrm{m}^{-1}$ in $0-20,20-40$ and $0-100 \mathrm{~cm}$ soil profiles, respectively, which were $88.11,86.91$ and $79.63 \%$ lower than corresponding $\mathrm{EC}_{\mathrm{e}}$ values prior to planting. The corresponding values in sandy loam soil were $3.02,3.69$ and $5.62 \mathrm{dS} \mathrm{m}^{-1}$, and were reduced by $89.51,86.75$ and $79.28 \%$.

Soil $\mathrm{pH}_{\mathrm{e}}$ value increased in 2012, decreased in 2013 and was stable in 2014, with values remaining at 7.5-8 after one year (Fig. 3). Similar trends were observed in both soils in $0-20 \mathrm{~cm}$ profiles; while there were significant differences in $20-40$ and $0-100 \mathrm{~cm}$ in 2013, with values lower in sandy loam than in silt soil. Average SAR values decreased dramatically in 2012, and slowly in 2013 and 2014 , and the decrease was higher in sandy loam than in silt soil during reclamation (Fig. 3). In March 2014, the average SAR values of the five treatments in silt soil were 21.04, 20.38 and 25.77 $\left(\mathrm{mmol} \mathrm{L}^{-1}\right)^{0.5}$ in $0-20,20-40$ and $0-100 \mathrm{~cm}$ profiles, respectively, which were $63.83,63.81$ and $55.17 \%$ lower than corresponding $\mathrm{EC}_{\mathrm{e}}$ values prior to planting. The corresponding values in sandy loam soil were $10.09,11.73$ and $14.72 \mathrm{dS} \mathrm{m}^{-1}$, and were reduced by 81.62 , 78.42 and $71.62 \%$.

The variations of $\triangle E C_{e}$ with reclamation time in different soil depths of the two soils were shown in Fig. 4. After enhanced salt leaching and period of irrigation for rose survival, the soil $\mathrm{EC}_{\mathrm{e}}$ decreased in all depths for two soils. The $\triangle \mathrm{EC}_{\mathrm{e}}$ values decreased from 21.88 to $6.74 \mathrm{dS} \mathrm{m}^{-1}$ with soil depth increasing for sandy loam soil, and the corresponding values were from 23.22 to $3.94 \mathrm{dS} \mathrm{m}^{-1}$ for silt soil. After nearly one month of saline water irrigation, the higher $\triangle E_{e}$ values occurred in $40-60$ and $30-40 \mathrm{~cm}$ soil depths for sandy loam and silt soils, respectively. After that, the main salt leaching layers were below $60 \mathrm{~cm}$ soil depth for both soils.

\subsection{Root growth}

Vertical distribution of root dry weight for the five saline irrigation treatments and the mean value in both soils are shown in Fig. 5. Root dry weight decreased with increasing irrigation water salinity and soil depth (Fig. $5 \mathrm{a}-\mathrm{e}$ ). The value in the $0-50 \mathrm{~cm}$ profile was $53.95 \mathrm{~g} /$ plant for $0.8 \mathrm{dS} \mathrm{m}^{-1}$ irrigation water in silt soil, $255.55 \%$ higher than that for $7.8 \mathrm{dS} \mathrm{m}^{-1}$ irrigation; in sandy loam soil, the corresponding value was $39.12 \mathrm{~g} /$ plant, and was $323.10 \%$ higher (Fig. 5f). Most roots were present in the upper $20 \mathrm{~cm}$ of soil ( 91.09 and $94.97 \%$ of the total root dry weights in the silt and sandy loam soils, respectively) (Fig. 5f). The decrease of root dry weight in $0-10 \mathrm{~cm}$ was higher in silt than in sandy loam soil with increased salinity of irrigation water. The average of root dry weights of the five treatments in $0-10 \mathrm{~cm}$ were the same in both soil types, but there was $51.71 \%$ of total root dry weight present in the $10-50 \mathrm{~cm}$ profile in silt soil, which was higher than $41.07 \%$ in sandy loam soil (Fig. 5f).

The responses of root length and $\beta$ to irrigation water salinity in both soils are shown in Fig. 6. Fine root length values decreased significantly with increasing salinity of irrigation water in silt soil from 2856.00 to $2052.69 \mathrm{~cm}$ (Fig. 6a), but the percentage of fine root length initially increased and then decreased (Fig. 6b). In sandy loam soil, the fine root length values initially increased and then 


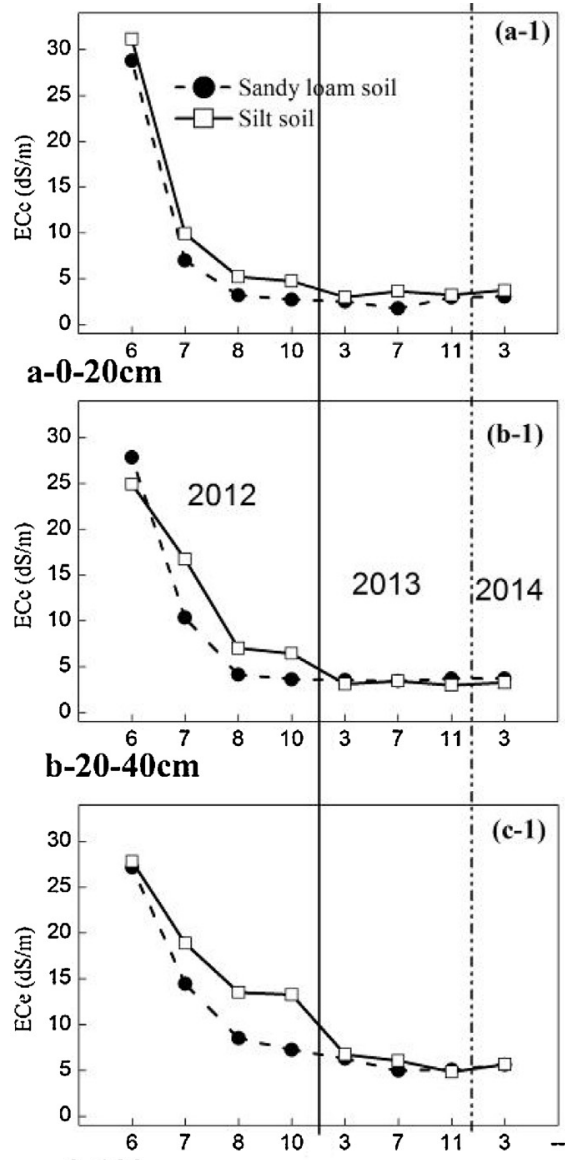

c-0-100cm Time/Month
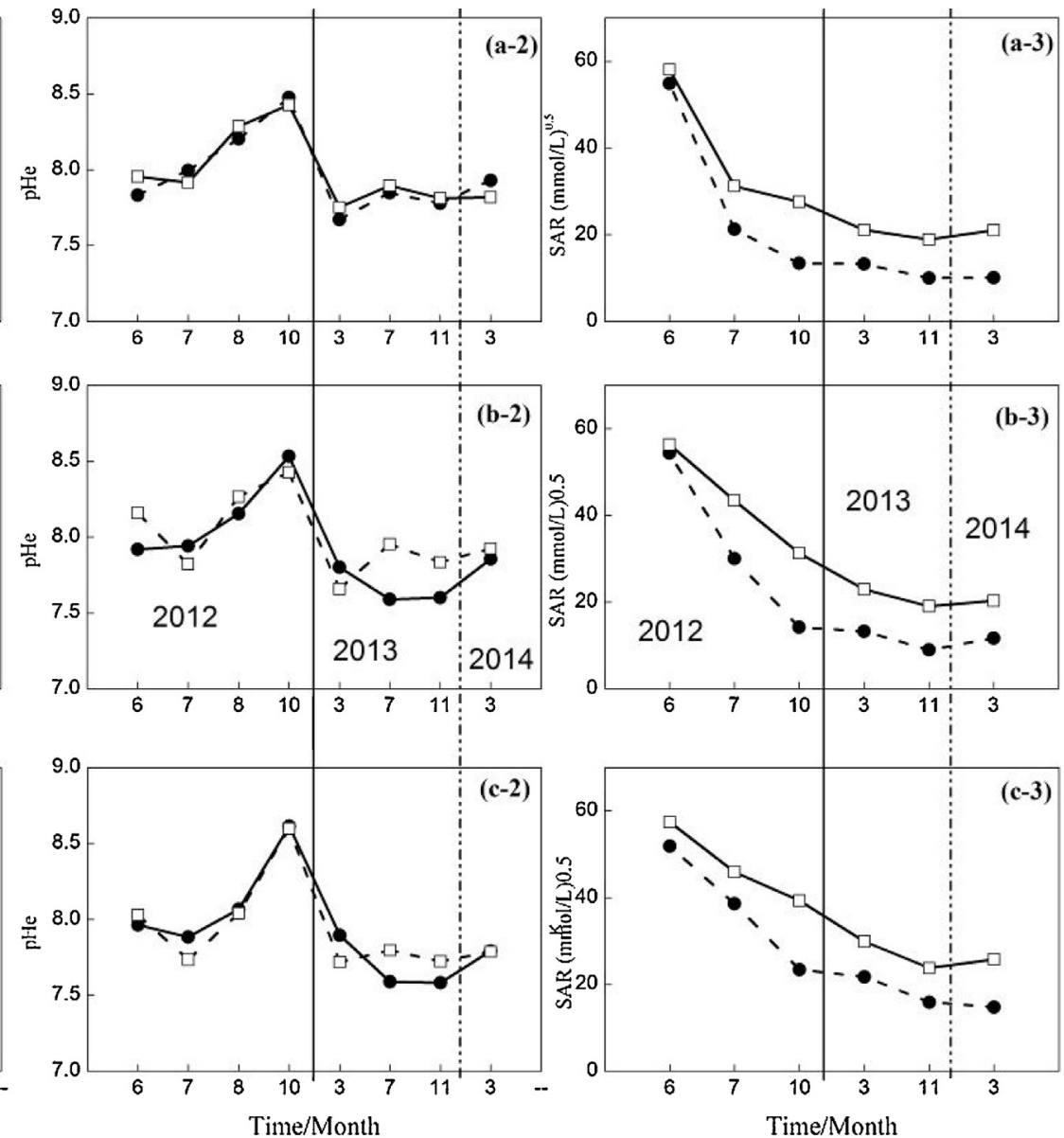

Fig. 3. The variations of $\mathrm{EC}_{\mathrm{e}}, \mathrm{pH}$ and $\mathrm{SAR}$ with reclamation time in different soil depths of the two soils.
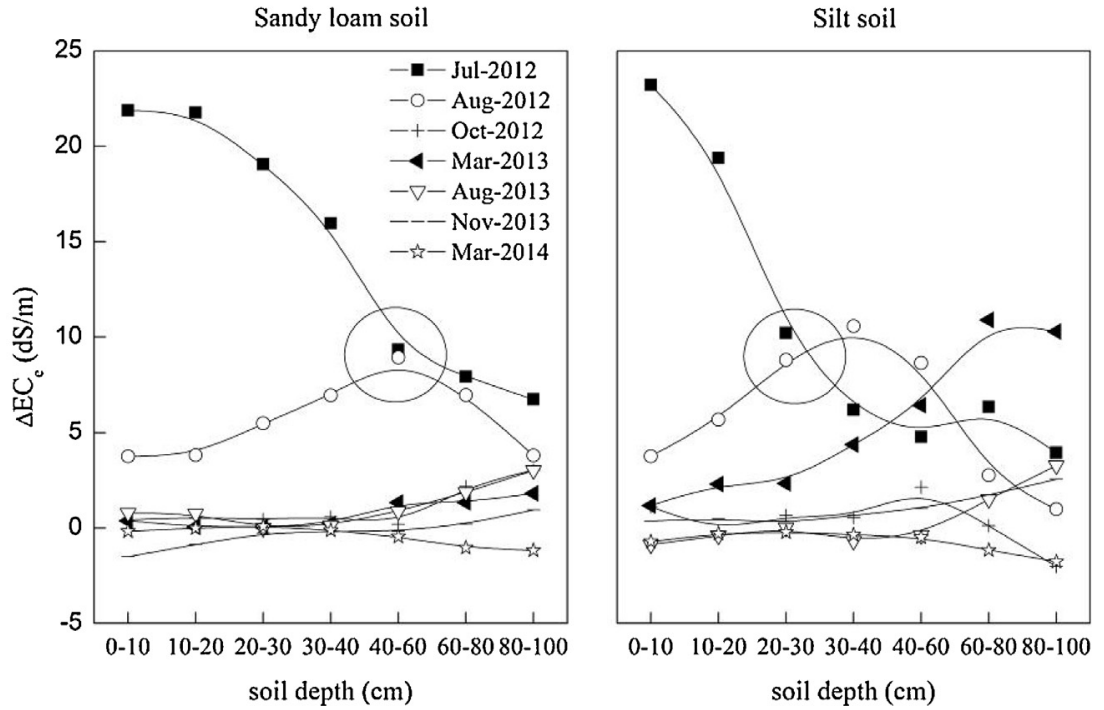

Fig. 4. The variations of $\Delta \mathrm{EC}_{\mathrm{e}}$ with reclamation time in different soil depths of the two soils.

decreased with increased salinity of irrigation water (Fig. 6a), and the percentage of fine root length increased from 89.52 to $96.01 \%$ (Fig. 6b). The fine root length values were 1.5-2 times higher in silt than in sandy loam soil. The coarse root length values initially decreased and then increased with increased salinity of irrigation water in silt, but decreased in sandy loam soil (Fig. $6 \mathrm{c}$ ). $\beta$ increased with increasing salinity of irrigation water up to $7.8 \mathrm{dS} \mathrm{m}^{-1}$ in both soils and then decreased (Fig. 6d), and $\beta$ was higher in silt than in sandy loam soil.

\subsection{Plant growth}

Both plant height and stem diameter were significantly affected by irrigation water salinity and reclamation time, while soil type 

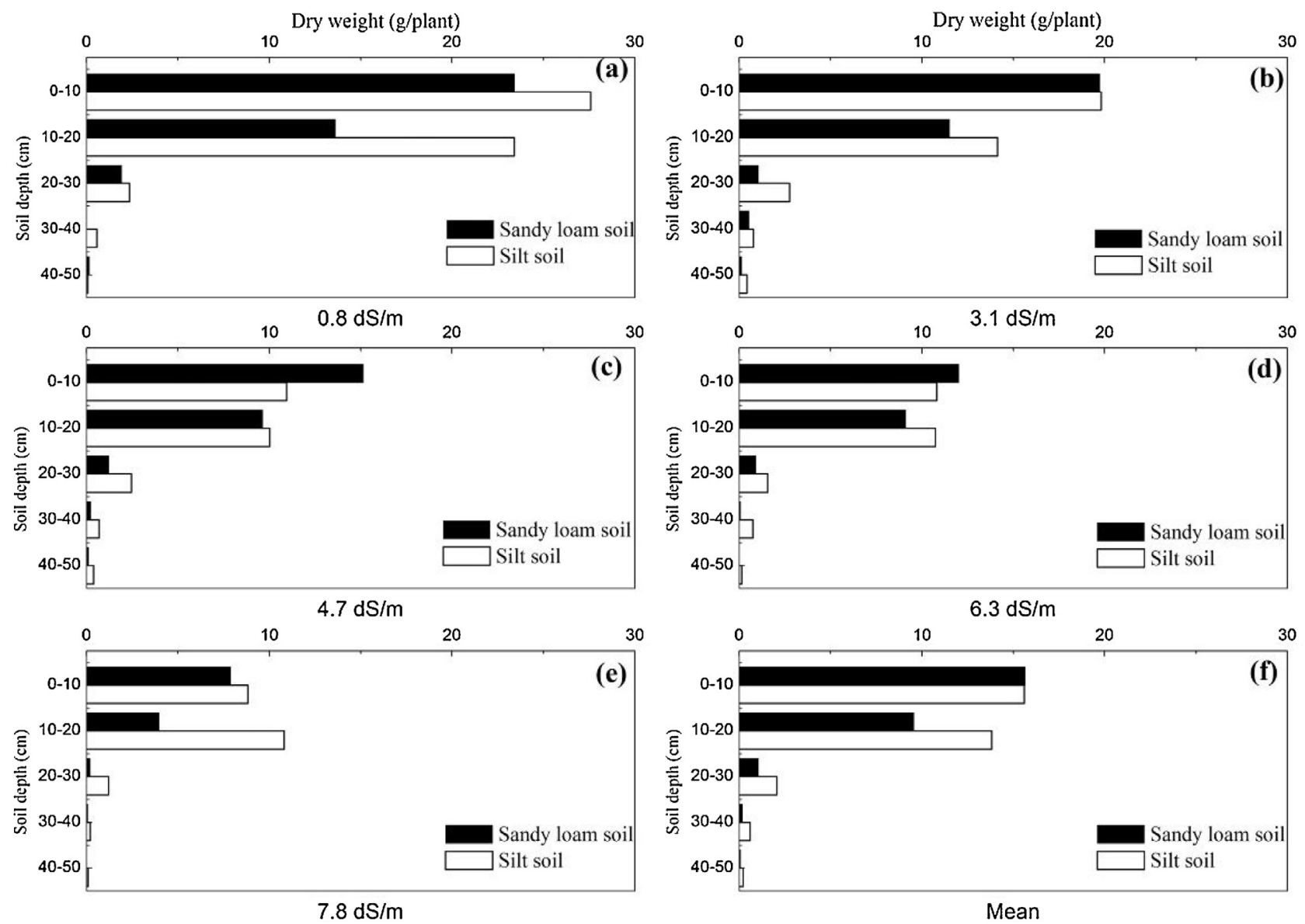

Fig. 5. The vertical distribution of plant dry weight at five levels of irrigation water salinity and the mean value in both soils during the experimental periods.

only significantly affected plant height (Table 3 ). Increasing irrigation water salinity significantly reduced plant height in both saline soils in 2012, and especially in 2013. Plant height decreased from 75.92 to $56.75 \mathrm{~cm}$ in sandy loam and 80.22 to $68.19 \mathrm{~cm}$ in silt soil in 2012 (Table 3); and correspondingly decreased from 108.27 to $78.91 \mathrm{~cm}$ and 117.03 to $92.90 \mathrm{~cm}$ in 2013 . The highest value of plant height in silt soil was for the treatment of $3.1 \mathrm{dS} \mathrm{m}^{-1}$ irrigation water, but was for the $0.8 \mathrm{dS} \mathrm{m}^{-1}$ treatment in sandy loam soil. The change of stem diameter showed the same trends as plant height with irrigation water salinity. Growth was better in silt than in sandy loam soil during the two experimental years.

\subsection{Dry mass}

Root and shoot dry mass significantly decreased with increasing salinity of irrigation water in both saline soils (Fig. 7). Root dry mass decreased from 39.12 to $12.11 \mathrm{~g} /$ plant in sandy loam and from 53.96 to $21.12 \mathrm{~g} /$ plant in silt soil, and correspondingly shoot dry mass decreased from 251.53 to $52.20 \mathrm{~g} /$ plant and 305.10 to $100.10 \mathrm{~g} /$ plant. Dry mass was greater in silt than in sandy loam soil. Root:shoot ratio increased with increasingly saline water in both soils, meaning plants devoted more dry matter to roots but less to shoots with increasing salinity of irrigation. Saline water had a greater effect on root:shoot ratio in sandy loam than in silt soil, and the ratios were higher in sandy loam than in silt soil when irrigated with saline water $>4.7 \mathrm{dS} \mathrm{m}^{-1}$.

WPE significantly decreased with the increasing salinity of irrigation water in both saline soils, especially in silt soil (Fig. 8). It decreased from 6.12 to $0.23 \mathrm{~g} \mathrm{~m}^{2} \mathrm{~mm}^{-1}$ in silt soil, and from 1.89 to $0.25 \mathrm{~g} \mathrm{~m}^{2} \mathrm{~mm}^{-1}$ in sandy loam soil. Higher WPE values occurred in silt soil than that in sandy loam soil when irrigated with saline water $<6.3 \mathrm{dS} \mathrm{m}^{-1}$.

\subsection{Ion absorption}

Ca and $\mathrm{Mg}$ concentrations in leaf increased significantly with increasing salinity of irrigation water in both soils (Table 4). The leaves of plants irrigated with $7.8 \mathrm{dS} \mathrm{m}^{-1}$ contained 479.10 and $439.26 \mathrm{mmol} \mathrm{kg}^{-1} \mathrm{Ca}$ in sandy loam and silt soils, respectively, and 236.47 and $211.87 \mathrm{mmol} \mathrm{kg}^{-1} \mathrm{Mg}$ compared to corresponding values of only 405.48 and $331.83 \mathrm{mmol} \mathrm{kg}^{-1} \mathrm{Ca}$ and 197.08 and $173.32 \mathrm{mmol} \mathrm{kg}^{-1} \mathrm{Mg}$ irrigated with $0.8 \mathrm{dS} \mathrm{m}^{-1}$. There was a significant difference in $\mathrm{Ca}$ absorption in both soils, and the average Ca concentration of the five treatments was $439.19 \mathrm{mmol} \mathrm{kg}^{-1}$ in sandy loam, higher than that in silt soil with $397.20 \mathrm{mmol} \mathrm{kg}^{-1}$. There was no obvious difference in $\mathrm{Mg}$ absorption in the two soil types.

There was no significant difference in $\mathrm{K}$ concentration in both soils for the five treatments. Na and phosphorus (P) concentrations in leaves were different with increasing salinity of irrigation in the two soils. There was only a slight increase in Na concentrations in sandy loam soil and P concentrations in silt soil. Saline water irrigation significantly increased Na concentration in leaves in silt soil with an average value of $75.73 \mathrm{mmol} \mathrm{kg}^{-1}$, compared with only $40.87 \mathrm{mmol} \mathrm{kg}^{-1}$ in sandy loam soil (Table 4). The P concentration increased from 79.51 to $101.46 \mathrm{mmol} \mathrm{kg}^{-1}$ in sandy loam and 57.88 to $60.79 \mathrm{mmol} \mathrm{kg}^{-1}$ in silt soil with increasing salinity of irrigation (Table 4). 

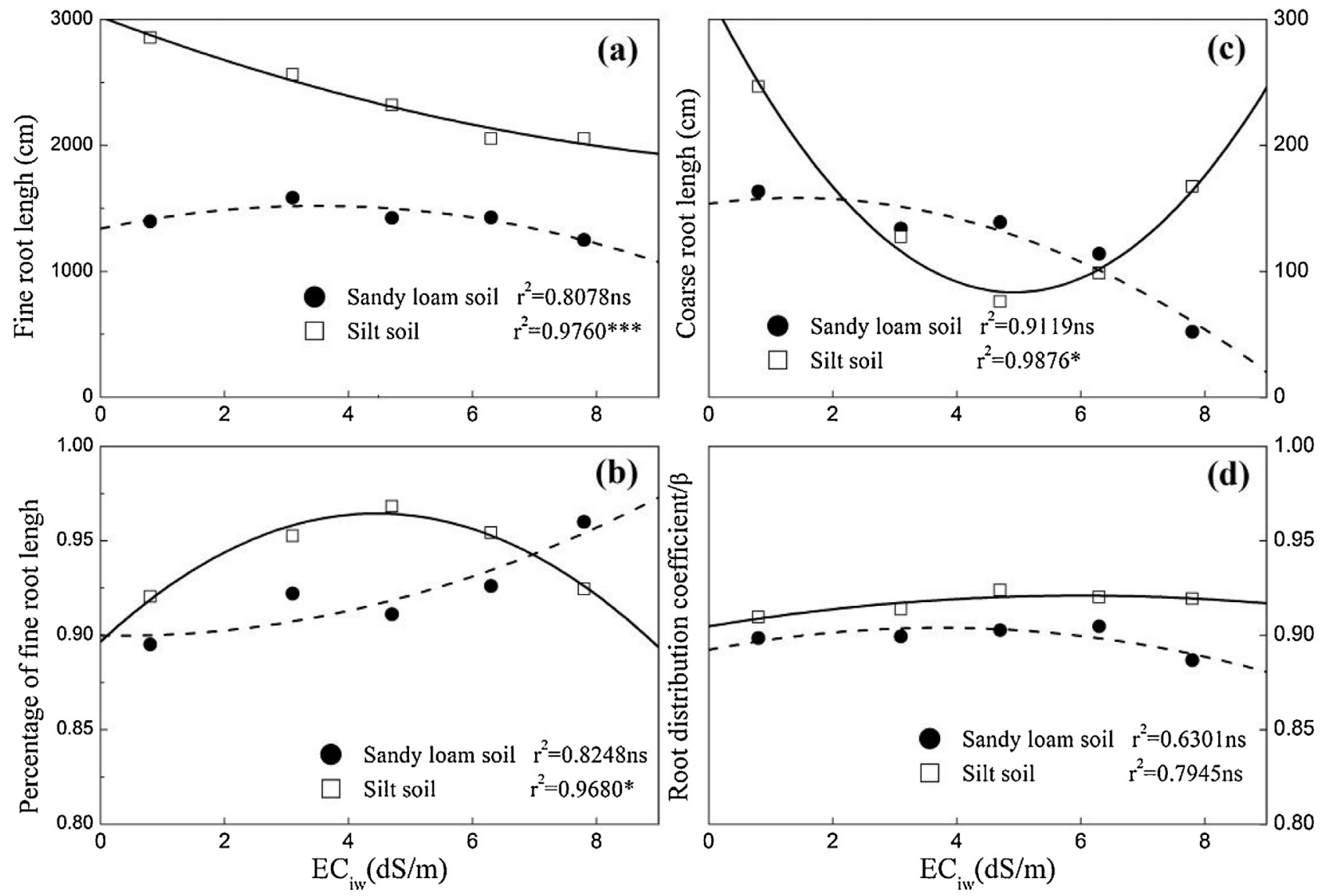

Fig. 6. The relationships between root parameters and $\mathrm{EC}_{\mathrm{iw}}$ in the two soils.

\subsection{Survival rate and emergence rate}

Emergence and survival rates of Chinese rose for the five treatments in both soils are shown in Table 5. Although there was an average survival rate of 94.40 and $98.67 \%$ in the first year and no significant difference among treatments in sandy loam and silt soils, the emergence rates in 2013 were reduced by $0.61,8.07,9.55$, 32.69 and $46.79 \%$, respectively, compared with initial survival rate in 2012 in sandy loam soil; and the corresponding values were 3.33 , $30.34,58.62,89.89$ and $91.01 \%$ in silt soil. In 2013 , the average sur-

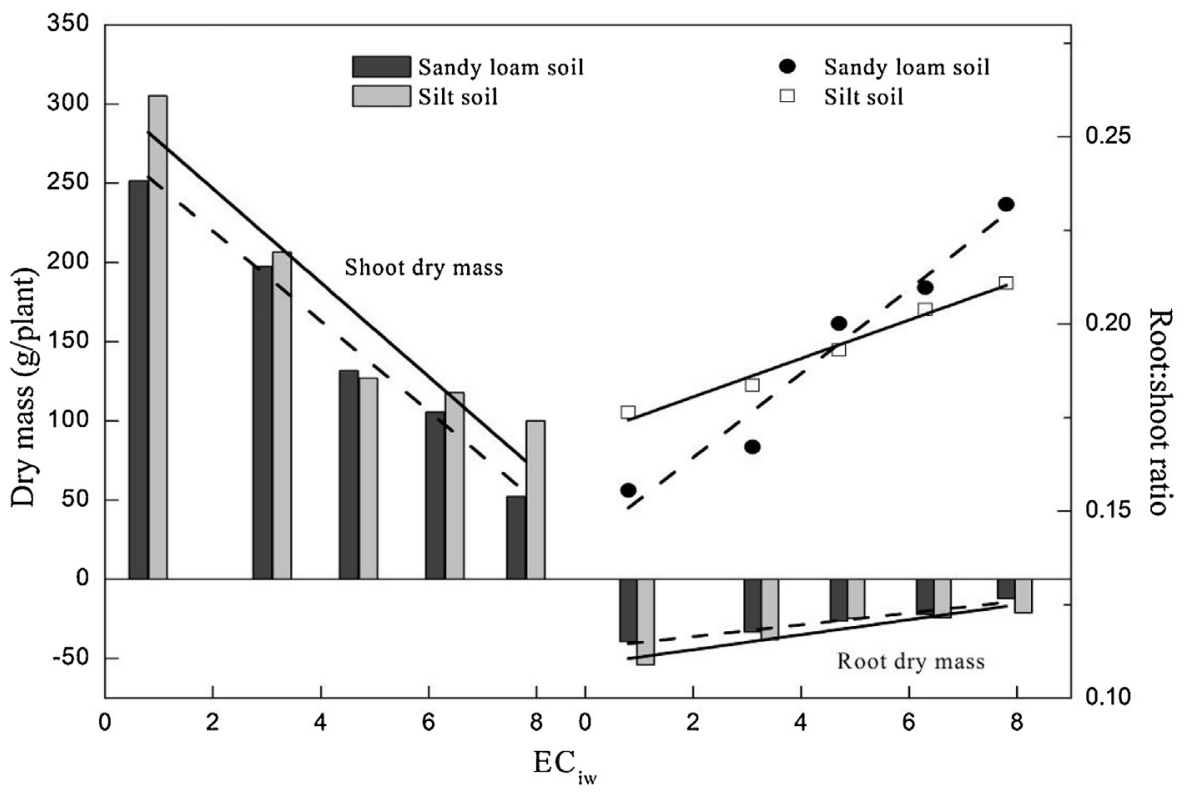

Fig. 7. The variation of shoot and root dry masses and root:shoot ration with $\mathrm{EC}_{\mathrm{iw}}$ in the two soils. 
Table 4

Ions concentration in plant leaves at different irrigation water quality $\left(\mathrm{EC}_{\mathrm{iw}}\right)$ in the two soils.

\begin{tabular}{|c|c|c|c|c|c|c|c|c|c|c|}
\hline \multirow[t]{2}{*}{ Treatments } & \multicolumn{2}{|c|}{$\begin{array}{l}\text { Ca concentration } \\
(\mathrm{mmol} / \mathrm{kg} \mathrm{DM})\end{array}$} & \multicolumn{2}{|c|}{$\begin{array}{l}\text { Mg concentration } \\
(\mathrm{mmol} / \mathrm{kg} \mathrm{DM})\end{array}$} & \multicolumn{2}{|c|}{$\begin{array}{l}\text { K concentration } \\
(\mathrm{mmol} / \mathrm{kg} \mathrm{DM})\end{array}$} & \multicolumn{2}{|c|}{$\begin{array}{l}\text { Na concentration } \\
(\mathrm{mmol} / \mathrm{kg} \mathrm{DM})\end{array}$} & \multicolumn{2}{|c|}{$\begin{array}{l}\text { P concentration } \\
\text { (mmol/kg DM) }\end{array}$} \\
\hline & Sandy loam & Silt & Sandy loam & Silt & Sandy loam & Silt & Sandy loam & Silt & Sandy loam & Silt \\
\hline $0.8 \mathrm{dS} / \mathrm{m}$ & 405.48 & 331.83 & 197.08 & 173.32 & 432.40 & 432.21 & 33.30 & 42.28 & 79.51 & 57.88 \\
\hline $3.1 \mathrm{dS} / \mathrm{m}$ & 415.84 & 399.42 & 194.21 & 190.96 & 419.57 & 423.31 & 37.52 & 41.20 & 85.72 & 58.19 \\
\hline $4.7 \mathrm{dS} / \mathrm{m}$ & 420.00 & 402.20 & 199.93 & 192.01 & 423.44 & 443.45 & 39.54 & 68.92 & 87.01 & 57.91 \\
\hline $6.3 \mathrm{dS} / \mathrm{m}$ & 475.51 & 413.31 & 202.82 & 209.40 & 436.61 & 444.29 & 44.50 & 86.26 & 101.46 & 60.79 \\
\hline $7.8 \mathrm{dS} / \mathrm{m}$ & 479.10 & 439.26 & 236.47 & 211.87 & 479.73 & 435.74 & 49.51 & 140.01 & 94.00 & 60.44 \\
\hline Mean & 439.19 & 397.20 & 206.10 & 195.51 & 438.35 & 435.80 & 40.87 & 75.73 & 89.54 & 59.04 \\
\hline \multicolumn{11}{|l|}{$\mathrm{LSD}_{0.05}$} \\
\hline Soil type & & $<0.001$ & & 0.091 & & 0.513 & & $<0.001$ & & $<0.001$ \\
\hline $\mathrm{EC}_{\mathrm{iw}}$ & & $<0.001$ & & 0.005 & & 0.305 & & $<0.001$ & & 0.027 \\
\hline Soil type $\times \mathrm{EC}_{\mathrm{iw}}$ & & 0.281 & & 0.421 & & 0.659 & & $<0.001$ & & 0.165 \\
\hline
\end{tabular}

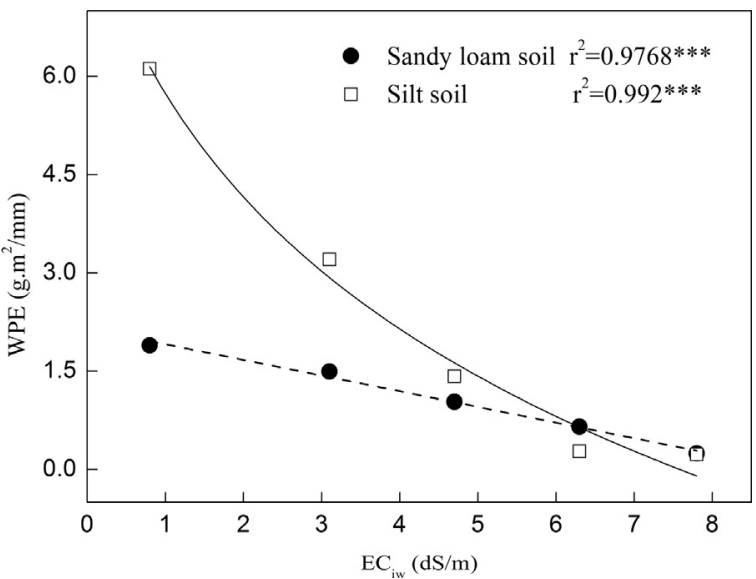

Fig. 8. The variation of water production efficiency (WPE) with $\mathrm{EC}_{\mathrm{iw}}$ in the two soils.

vival rate in sandy loam was $75.24 \%$ and was 1.68 times that in silt soil with $44.89 \%$. Emergence and survival rates remained relatively stable in 2014 compared with 2013.

Soil type, reclamation time and salinity of irrigation water significantly affected the survival rate of rose during soil reclamation. Soil type and salinity of irrigation also significantly affected the emergence rate of rose; while the effect of reclamation time was limited-emergence rate was only obviously affected in the first emergence period, with no significant difference after that.

\section{Discussion}

The significant reduction in soil salinity and SAR during reclamation of saline soils suggested that drip irrigation was an effective technique and very useful for utilization and reclamation of saline soils (Kang et al., 2010; Liu et al., 2012; Sun et al., 2013; Wan et al., 2012; Wang et al., 2013). Chinese roses, sensitive to salinity, had high survival rates under drip irrigation with saline water in the growth period, which appeared to further support that drip irrigation is a promising system to use with saline water (Malash et al., 2008; Meiri et al., 1992).

Soil salt leaching rate was initially different during reclamation in sandy loam and silt saline soils after enhanced salt leaching and period of irrigation for rose survival (July 2012), especially in the subsoil profile, due to different soil hydraulic conductivities (data not shown). Two months later (August 2012), the average $\mathrm{EC}_{\mathrm{e}}$ value of the five irrigation water treatments was $13.53 \mathrm{dS} \mathrm{m}^{-1}$ in $0-100 \mathrm{~cm}$ in silt soil (Fig. $3 \mathrm{c}-1$ ); in comparison, salinity was reduced more rapidly in sandy loam soil to a corresponding value of $8.52 \mathrm{dS} \mathrm{m}^{-1}$ (Fig. 3c-1). However, there was no significant difference between the two soils in the late stage of salt leaching. The initial stage seemed to be critical for salt leaching; thus improving soil infiltration by tillage as in the present study, or applying plaster in the initial period may be effective in shortening the time required for salt leaching. This would benefit the survival of plants during reclamation of very heavy saline soils, especially those with poor infiltration.

Table 5

Chinese rose emergence and survival rate at different irrigation water quality ( $\left.\mathrm{EC}_{\mathrm{iw}}\right)$ in the two soils from 2012 to 2014.

\begin{tabular}{|c|c|c|c|c|c|c|c|c|c|c|}
\hline \multirow[t]{3}{*}{ Treatments } & \multicolumn{6}{|c|}{ Survival rate (\%) } & \multicolumn{4}{|c|}{ Emergence rate (\%) } \\
\hline & \multicolumn{2}{|l|}{2012} & \multicolumn{2}{|l|}{2013} & \multicolumn{2}{|l|}{2014} & \multicolumn{2}{|l|}{2013} & \multicolumn{2}{|l|}{2014} \\
\hline & Sandy loam & Silt & Sandy loam & Silt & Sandy loam & Silt & Sandy loam & Silt & Sandy loam & Silt \\
\hline $0.8 \mathrm{dS} / \mathrm{m}$ & 97.02 & 100.00 & 96.43 & 96.67 & 96.36 & 96.67 & 96.43 & 96.67 & 96.36 & 96.67 \\
\hline $3.1 \mathrm{dS} / \mathrm{m}$ & 95.83 & 98.89 & 86.90 & 68.89 & 80.61 & 67.78 & 88.10 & 68.89 & 86.06 & 67.78 \\
\hline $4.7 \mathrm{dS} / \mathrm{m}$ & 93.45 & 96.67 & 83.93 & 40.00 & 77.80 & 33.33 & 84.52 & 40.00 & 83.81 & 33.33 \\
\hline $6.3 \mathrm{dS} / \mathrm{m}$ & 92.86 & 98.89 & 61.35 & 10.00 & 51.68 & 8.89 & 62.50 & 10.00 & 61.31 & 8.89 \\
\hline $7.8 \mathrm{dS} / \mathrm{m}$ & 92.86 & 98.89 & 47.62 & 8.89 & 36.54 & 7.78 & 49.40 & 8.89 & 47.41 & 7.78 \\
\hline Mean & 94.40 & 98.67 & 75.24 & 44.89 & 68.60 & 42.89 & 76.19 & 44.89 & 75.00 & 42.89 \\
\hline \multicolumn{11}{|l|}{$\mathrm{LSD}_{0.05}$} \\
\hline Soil type & & & $<0.001$ & & $<0.001$ & & & & & \\
\hline $\mathrm{EC}_{\mathrm{iw}}$ & & & $<0.001$ & & $<0.001$ & & & & & \\
\hline Year & & & $<0.001$ & & 0.682 & & & & & \\
\hline Soil type $\times$ EC & & & 0.003 & & $<0.001$ & & & & & \\
\hline Soil type $\times \mathrm{Ye}$ & & & $<0.001$ & & 0.918 & & & & & \\
\hline $\mathrm{EC}_{\mathrm{iw}} \times$ Year & & & $<0.001$ & & 0.999 & & & & & \\
\hline Soil type $\times$ EC & Year & & 0.223 & & 0.998 & & & & & \\
\hline
\end{tabular}


The main salt leaching layer moved down with the reclamation time (Fig. 4). After enhanced salt leaching and period of irrigation for rose survival (July 2012), the main salt leaching layers were in 0-40 and 0-20 cm soil depths for sandy loam soil and silt soils, respectively. Similar $\triangle \mathrm{EC}_{\mathrm{e}}$ values occurred in $40-60$ and $20-30 \mathrm{~cm}$ soil depths for both soils. It indicated that better salt leaching effect occurred in sandy loam soil than in silt soil. Then in the next month with saline water irrigation (August 2012), the $40-60$ and $30-40 \mathrm{~cm}$ were the main salt leaching layer for sandy loam and silt soils. After that, the main salt leaching layer moved down to deep soil depths below $60 \mathrm{~cm}$. Thus, it is beneficial to deepen the main salt leaching layer in silt soil in the early time through some measures to increase soil infiltration, further improve the survival of plants during reclamation of very heavy saline soils.

Regardless of soil type and irrigation water salinity, soil $\mathrm{pH}_{\mathrm{e}}$ initially increased from 8 to 8.5 , and then decreased to 7.5-8 (Fig. 3a-2, b-2 and c-2). This confirmed that soil alkalization occurred in the early stage of irrigation with saline water, likely from reduction in soil salinity and higher $\mathrm{pH}_{\mathrm{e}}$ of irrigation water than $\mathrm{pH}_{\mathrm{e}}$ in the soil profile before transplanting. In contrast, $\mathrm{pH}_{\mathrm{e}}$ declined in 2013 and 2014, likely because decreased SAR, soil respiration, soil humus and fertilization may also play a role in the $\mathrm{pH}_{\mathrm{e}}$ change (Chowdhury et al., 2011; Wang et al., 2011 Yuan et al., 2007). Similar results were obtained by Sun et al. (2012b) in other coastal region. The $\mathrm{pH}_{\mathrm{e}}$ results implied that a soluble acid such as industrial phosphoric acid should be applied during the initial stage of saline soil reclamation, which would benefit plants that prefer acid soils.

Root biomass, root length, plant growth, ion absorption and emergence rate were significantly affected by salinity in both soils. Increasing salinity of irrigation water significantly reduced root biomass in both the sandy loam and silt soils. Roots mainly grew in the $0-20 \mathrm{~cm}$ profile regardless of soil type and salinity, and on average 94.98 and $91.09 \%$ of root biomass was in this layer in sandy loam and silt soils, respectively (Fig. 5f). For sandy loam soil, more of the roots were concentrated in the surface $0-10 \mathrm{~cm}$ than in silt soil, representing 58.93 and $48.29 \%$ of the total root biomass, respectively (Fig. 5f)-which differed from previous results showing that deeper roots were much more likely in coarse- than in medium-textured soils (Schenk and Jackson, 2002, 2005). Field and plant-available water capacities are lower in coarse- than in medium-textured soils (Saxton et al., 1986), leading to greater infiltration depths and potentially greater rooting depths (Jackson et al., 1999). In the present study, SMP was controlled by tensiometers installed $0.2 \mathrm{~m}$ directly underneath emitters, which caused a vertical downward gradient of soil water potential and was beneficial for salt leaching, likely leading to the opposite root distribution compared with natural conditions.

In sandy loam soil, coarse root length was markedly decreased, while fine root length initially increased and then decreased with an increase in salinity of irrigation. In silt soil, the opposite was observed-fine root length decreased markedly with irrigation water salinity, but coarse root lengths initially decreased and then increased. Combined with drought occurring more easily in sandy loam soil, the result implied that fine roots were developed as a priority under drought combined with salinity stress, while coarse roots were a priority under salinity stress. The percentage of fine root lengths increased except for higher salinity treatments and may be a mechanism for plants to adapt to salinity.

$\beta$ increased as salinity levels increased in both soils, further suggesting that rose plants were salt-intolerant and proportionately more deeply rooted when subject to salinity (Gale and Grigal, 1987). However, $\beta$ was reduced under treatments with saline water of 7.8 and $>6.3 \mathrm{dS} \mathrm{m}^{-1}$ in sandy loam and silt soils, respectively (Fig. 6). This could be attributed to a significant reduction in root growth under higher salinity conditions, and was also consistent with the observed decrease in root length density in all soil layers under higher salinity treatments (data not shown).

Stem diameter, and especially plant height, was reduced significantly by salinity either from soil or irrigation water. Dry matter production (root and shoot dry mass) also declines due to the decreased light interception from a reduction in leaf area and results in reduced leaf photosynthesis under saline conditions (Alarcon et al., 1994; Kutuk et al., 2004; Li and Stanghellini, 2001). In the present study, roses grew better and produced more dry matter in silt than in sandy loam soil under the same treatments of salinity of irrigation, moreover lower WPE occurred in sandy loam soil than in silt soil for the treatment with similar survival rate, likely due to poor fertilizer conservation in sandy loam soil. Increasing root:shoot ratios suggested that plants devoted less dry matter to shoots and more to roots with increasing salinity levels, and this ratio was more affected by salinity in sandy loam than in silt soil due to the poor fertilizer and water conservation. However, an opposite result was observed by Valdez-Aguilar et al. (2011), who reported that both plant parts were equally affected by increasing $\mathrm{EC}_{\mathrm{iw}}$ as suggested by the lack of a significant effect on the shoot:root ratio of the five species studied. This is likely correlated with the different plant types with arbors in their research and bushes used in the current study. Most bushes are more sensitive to salinity than arbors and so may require adjusting the root:shoot ratio to adapt to a saline environment.

There was a marked difference in ion absorption in the two soils. $\mathrm{Ca}$ and $\mathrm{P}$ concentrations in plant leaves were higher for sandy loam than silt soil, while Na concentration was higher for silt. This may be due to the higher SAR in silt soil in 2013, with average values of 20.02 compared with $11.61\left(\mathrm{mmol} \mathrm{L}^{-1}\right)^{0.5}$ in sandy loam soil in the 0-20 cm profile (Fig. 3a-3). High SAR in soil can cause a buildup of $\mathrm{Na}$ in plant tissues, which interferes with the uptake of nutrients and disturbs plant growth (Naidu and Rengasamy, 1993). Another reason may be that the higher Ca concentration in leaves of plants in sandy loam soil reduced $\mathrm{Na}$ accumulation. In addition, lower SMP of $-15 \mathrm{kPa}$ was controlled in sandy loam soil after September 2013, and this probably caused water stress and the rapid loss of leaves from plants and these dropped leaves were likely of higher Na concentration.

$\mathrm{Na}$ in saline environments cause a reduction of $\mathrm{K}$ uptake by plants, and high $\mathrm{K}$ concentrations in tissues are associated with salt tolerance in many plant species (Barbosa et al., 2012; Grewal, 2010; Khatun and Flowers, 1995; Niu et al., 2013; Turner et al., 2013). However, contrasting results of no reduction or even a slight increase of K concentration in leaves of plants were observed in the present study in the two saline soils, possibly because sampling was at the end of the growth season. The leaves with reduced K concentrations following salt stress had likely fallen off, and so there was no difference in K concentrations in the remaining leaves.

Survival rate significantly decreased with salinity in irrigation water in 2013 due to the marked reduction in emergence rate in the spring of 2013 in sandy loam and especially in silt soil. This suggested that rose was more sensitive to salt at emergence stages of growth. Similar results were obtained by Rhoades et al. (1992), who reported that plants were more sensitive during emergence and early stages of seedling growth. Thus it is imperative to keep the salinity in the root zone low at these stages, and pre-emergence irrigation with non-saline water would play an important role in reducing the salt level in such cases (Chauhan et al., 2008). Emergence rates were nearly the same in the two soils for the treatment with $0.8 \mathrm{dS} \mathrm{m}^{-1}$ irrigation water, and significantly decreased for irrigation with $>3.1 \mathrm{dS} \mathrm{m}^{-1}$ in both soils. This is likely due to the higher soil salt in the root zone, which exceeded the salt tolerance threshold in the emergence period. The salt tolerance threshold in the root zone of silt soil was $2.24 \mathrm{dS} \mathrm{m}^{-1}$ for rose at emergence stages according to analysis of the linear relationship between 
soil root-zone $\mathrm{EC}_{\mathrm{e}}$ and emergence rates at emergence stage by Mass function (Li et al., 2015), and the corresponding value was $2.39 \mathrm{dS} \mathrm{m}^{-1}$ in sandy loam soil. This implied that salt tolerance threshold in the root zone in the emergence period did not obviously differ for the soil types for the same plants. There was a reduction in survival rate in 2013 and 2014 in sandy loam after the emergence period, but not in silt soil. The reasons may be related to the lower plant-available water capacities due to lower field water capacities and deeper infiltration in sandy loam soil (Jackson et al., 1999), although the same SMP was controlled during the experimental period. Irrigation was only applied in morning or night because the tensiometer values were read at these times, so drought may have occurred in the other times for the sandy loam soil, which could enhance the effect of salinity on plant growth. This confirmed that adequate soil moisture should be maintained to reduce any detrimental effects of salinity on plant growth.

Emergence rates were lower in silt than in sandy loam soil for irrigation water of salinity $>3.1 \mathrm{dS} \mathrm{m}^{-1}$ in the current study. There may be three reasons: first, the higher SAR value in silt soil in spring of 2013 caused a buildup of Na in plant tissues, which had negative effects on electron transport and photosynthesis, and also reduced assimilate supply through stomatal closure (Muranaka et al., 2002). Second, the increase of Ca concentration in plants in sandy loam played an important role in processes that preserve the structural and functional integrity of plant membranes, regulate ion transport and control activities of cell wall enzymes (Rengel, 1992). Third, roots penetrated further beyond the surface $0-20 \mathrm{~cm}$ that had lower salinity and SAR, into the subsoil in silt than in sandy loam soil-it is clear that salinity can have serious effects on plant emergence even if there are fewer roots in the saline zone and plants have access to non-saline or low-salinity surface soils. Moreover, correlation coefficients between emergence rate and soil $\mathrm{EC}_{\mathrm{e}}$ and SAR in the $0-40 \mathrm{~cm}$ were higher than in the $0-20 \mathrm{~cm}$ profile in silt soil (data not shown), while there was an opposite trend in sandy loam soil, which further confirmed that under saline conditions the roots penetrated deeper in silt than in sandy loam soil and led to detrimental effects on plant emergence during the seedling period. Although a buildup of salinity in the $0-40 \mathrm{~cm}$ soil layer occurred in the spring of 2014, the emergence rate of rose remained relatively stable for all treatments, likely due to higher tolerance of rose to salt and reduction of SAR with increased age. Thus the seedling period was a critical stage, and a low salt environment and SAR should be rapidly created in the root zone for plants especially during reclamation of saline soils.

In this study, the economic feasibility of the method to reclaim the two coastal saline soils is also an important factor in the application. Presently the main method of vegetation rehabilitation in the coastal saline regions of China is to replace saline soil with non-saline soil for depths of $0-100 \mathrm{~cm}$. However, this method is expensive with total current costs of $100-115 \mathrm{RMB} / \mathrm{m}^{2}$ including soil treatment, irrigation system and planting and maintenance costs to plant Chinese rose (data from survey). This compares to the total costs using our approach of $43-55 \mathrm{RMB} / \mathrm{m}^{2}$ (including soil treatment of 20-25 RMB, drip-irrigation system material of 3-5 RMB and 20-25 RMB for planting and maintenance) to plant Chinese rose in coastal heavy saline soils as this study. Thus, the cost of our method is about one-half of the total costs by the method of replacing saline soil with non-saline soil. This would save a lot of money for saline landscape construction, and in turn promote ecological environment construction in coastal areas, as well as accelerating economic and social development of coastal areas.

\section{Conclusions}

Soil type had an important impact on the reclamation process and consequently affected the plant growth, dry matter production, ion balance and initial germination. A better salt leaching effect was found in sandy loam soil in the early period of reclamation, while the dry mass production and plant growth were relatively low and poor compared with the silt soil due to poor fertilizer and water conservation, which implied that nutrient supply and adequate soil moisture should be carefully maintained during sandy loam reclamation. Most roots were present in the $0-20 \mathrm{~cm}$ profile in both soils under SMP controlled conditions. Compared to the rapid reclamation process in sandy loam, higher SAR and salinity caused a lower emergence rate in silt soil for the same salinity of irrigation water. Thus, during reclamation in silt soil, suitable soil root-zone environments should be rapidly created during the plant emergence period. Moreover, the salt tolerance threshold in the root zone during the emergence period was similar in both soils, but earlier drought in sandy loam soil enhanced the effect of salinity on plant growth. The results of this study have important implications for ecological construction in different saline soils with high $\mathrm{EC}_{\mathrm{e}}$ and SAR under drip irrigation with saline water, and water and nutrient management should be developed according to the soil properties. In addition, long-term monitoring is required to determine the response of plants during the continued reclamation processes of soils.

\section{Acknowledgements}

This study was supported by the National Key Technology R\&D Program of China (Grant No. 2013BAC02B02 and 2013BAC02B01), the Knowledge Innovation Program of the Chinese Academy of Sciences (Grant No. KZCX2-YW-359), and the Action Plan for the Development of Western China of the Chinese Academy of Sciences (Grant No. KZCX2-XB3-16).

\section{References}

Akhter, J., Murray, R., Mahmood, K., Malik, K.A., Ahmed, S., 2004. Improvement of degraded physical properties of a saline-sodic soil by reclamation with kallar grass (Leptochloa fusca). Plant Soil 258, 207-216.

Alarcon, J.J., Bolarin, M.C., Sanchezblanco, M.J., Torrecillas, A., 1994. Growth, yield and water relations of normal fruited and cherry tomato cultivars irrigated with saline water. J. Hortic. Sci. 69, 283-288.

Barbosa, F.D., de Lacerda, C.F., Gheyi, H.R., Farias, G.C., Silva, R.J.D., Lage, Y.A., Hernandez, F.F.F., 2012. Yield and ion content in maize irrigated with saline water in a continuous or alternating system. Cienc. Rural 42, 1731-1737.

Chauhan, C.P.S., Singh, R.B., Gupta, S.K., 2008. Supplemental irrigation of wheat with saline water. Agric. Water Manag. 95, 253-258.

Chowdhury, N., Nakatani, A.S., Setia, R., Marschner, P., 2011. Microbial activity and community composition in saline and non-saline soils exposed to multiple drying and rewetting events. Plant Soil 348, 103-113.

Crescimanno, G., Garofalo, P., 2006. Management of irrigation with saline water in cracking clay soils. Soil Sci. Soc. Am. J. 70, 1774-1787.

Darvishi, H.H., Dadnia, M.R., 2012. Effects of irrigation with saline water in production of two cultivars of sweet sorghum (Sorghum bicolor L.). Res. Crops $13,100-102$.

Gale, M.R., Grigal, D.F., 1987. Vertical root distributions of northern tree species in relation to successional status. Can. J. For. Res. 17, 829-834.

Grewal, H.S., 2010. Response of wheat to subsoil salinity and temporary water stress at different stages of the reproductive phase. Plant Soil 330, 103-113.

Hadi, J., Raijadhav, S.B., 2007. Response of saline water irrigation on Rangpur lime seedlings. Indian J. Hortic. 64, 37-40.

Jackson, R.B., Moore, L.A., Hoffmann, W.A., Pockman, W.T., Linder, C.R., 1999. Ecosystem rooting depth determined with caves and DNA. Proc. Natl. Acad. Sci. U. S. A. 96, 11387-11392.

Kang, Y., Chen, M., Wan, S., 2010. Effects of drip irrigation with saline water on waxy maize (Zea mays L. var. ceratina Kulesh) in North China Plain. Agric. Water Manag. 97, 1303-1309.

Khatun, S., Flowers, T.J., 1995. Effects of salinity on seed set in rice. Plant Cell Environ. 18, 61-67.

Kutuk, C., Cayci, G., Heng, L.K., 2004. Effects of increasing salinity and N-15-labelled urea levels on growth, $\mathrm{N}$ uptake, and water use efficiency of young tomato plants. Aust. J. Soil Res. 42, 345-351.

Li, Y.L., Stanghellini, C., 2001. Analysis of the effect of EC and potential transpiration on vegetative growth of tomato. Sci. Hortic. 89, 9-21.

Liu, S., Kang, Y., Wan, S., Wang, Z., Liang, Z., Jiang, S., Wang, R., 2012. Germination and growth of Puccinellia tenuiflora in saline-sodic soil under drip irrigation. Agric. Water Manag. 109, 127-134. 
Li, X., Kang, Y., Wan, S., Chen, X., Chu, L., 2015. Reclamation of very heavy coastal saline soil using drip-irrigation with saline water on salt sensitive plants. Soil Tillage Res. 146, 159-173.

Malash, N.M., Ali, F.A., Fatahalla, M.A., Khatab, E.A., Hatem, M.K., Tawfic, S., 2008. Response of tomato to irrigation with saline water applied by different irrigation methods and water management strategies. Int. J. Plant Prod. 2 101-116.

Meiri, A., Frenkel, H., Mantell, A., 1992. Cotton response to water and salnity under sprinkler and drip irrigation. Agron. J. 84, 44-50.

Muranaka, S., Shimizu, K., Kato, M., 2002. Ionic and osmotic effects of salinity on single-leaf photosynthesis in two wheat cultivars with different drought tolerance. Photosynthetica 40, 201-207.

Naidu, R., Rengasamy, P., 1993. Ion interactions and constraints to plant nutrition in Australian sodic soils. Aust. J. Soil Res. 31, 801-819.

Niu, G.H., Rodriguez, D.S., Wang, M.Z., Starman, T., Zhang, D.L., 2011. Responses of Zinnia to saline water irrigation. In: Fernandez, J.E., Ferreira, M.I. (Eds.), XXVIII International Horticultural Congress on Science and Horticulture for People. Acta Hortic 922, 237-243.

Niu, G.H., Wang, M.Z., Rodriguez, D., Zhang, D.L., 2012. Response of Zinnia plants to saline water irrigation. Hortscience 47, 793-797.

Niu, G.H., Starman, T., Byrne, D., 2013. Responses of growth and mineral nutrition of garden roses to saline water irrigation. HortScience 48, 756-761.

Oster, J.D., Shainberg, I., Abrol, I.P., 1999. Reclamation of salt affected soils. In: Skaggs, R.W., Van Schilfgaarde, J. (Eds.), Agricultural Drainage. ASA-CSSA-SSSA, Madison, WI, pp. 659-691.

Ozrad, M., Gornat, B., Goldberg, D., 1972. Soil leaching and irrigation by tricking with saline water. Isr. J. Agric. Res. 22, 151-163.

Rengasamy, P., Chittleborough, D., Helyar, K., 2003. Root-zone constraints and plant-based solutions for dryland salinity. Plant Soil 257, 249-260.

Rengel, Z., 1992. The role of caluium in sale toxicity. Plant Cell Environ. 15, 625-632.

Rhoades, J.D., Kandiah, A., Mashali, A.M., 1992. The Use of Saline Waters for Crop Production. Food and Agriculture Organization Of The United Nations, pp. $1-132$

Rhoades, J.D., et al., 1988. Reuse of drainage water for irrigation-results of imperiar-valley study. 2. Soil-salinity and water-balance. Hilgardia 56, 17-44.

Sa, F.V.D., Brito, M.E.B., de Melo, A.S., Neto, P.A., Fernandes, P.D., Ferreira, I.B., 2013. Production of papaya seedlings irrigated with saline water. Rev. Bras. Eng. Agric. Ambient. 17, 1047-1054.
Saxton, K.E., Rawls, W.J., Romberger, J.S., Papendick, R.I., 1986. Estimating generalized soil-water characteristics from texture. Soil Sci. Soc. Am. J. 50, 1031-1036.

Schenk, H.J., Jackson, R.B., 2002. The global biogeography of roots. Ecol. Monogr. 72, 311-328.

Schenk, H.J., Jackson, R.B., 2005. Mapping the global distribution of deep roots in relation to climate and soil characteristics. Geoderma 126, 129-140.

Sumner, M.E., 1993. Sodic soils-new perspectives. Aust. J. Soil Res. 31, 683-750.

Sun, J., Kang, Y., Wan, S., Hu, W., Jiang, S., Zhang, T., 2012a. Soil salinity management with drip irrigation and its effects on soil hydraulic properties in north China coastal saline soils. Agric. Water Manag. 115, 10-19.

Sun, J.X., Kang, Y.H., Wan, S.Q., Hu, W., Jiang, S.F., Zhang, T.B., 2012b. Soil salinity management with drip irrigation and its effects on soil hydraulic properties in north China coastal saline soils. Agric. Water Manag. 115, 10-19.

Sun, J.X., Kang, Y.H., Wan, S.Q., 2013. Effects of an imbedded gravel-sand layer on reclamation of coastal saline soils under drip irrigation and on plant growth. Agric. Water Manag. 123, 12-19.

Turner, N.C., et al., 2013. Salinity tolerance and ion accumulation in chickpea (Cicer arietinum L.) subjected to salt stress. Plant Soil 365, 347-361.

Valdez-Aguilar, L.A., Grieve, C.M., Razak-Mahar, A., McGiffen, M.E., Merhaut, D.J., 2011. Growth and ion distribution is affected by irrigation with saline water in selected landscape species grown in two consecutive growing seasons: spring-summer and fall-winter. Hortscience 46, 632-642.

Van Reeuvijk, L.P. (Ed.), 2002. ISRIC, Wageningen.

Wan, S., Jiao, Y., Kang, Y., Hu, W., Jiang, S., Tan, J., Liu, W., 2012. Drip irrigation of waxy corn (Zea mays L. var. ceratina Kulesh) for production in highly saline conditions. Agric. Water Manag. 104, 210-220.

Wang, et al., 1993. China Saline and Sodic Soils. Science Press, Beijing, pp. 145.

Wang, R.S., Kang, Y.H., Wan, S.Q., Hu, W., Liu, S.P., Liu, S.H., 2011. Salt distribution and the growth of cotton under different drip irrigation regimes in a saline area. Agric. Water Manag. 100, 58-69.

Wang, L., Zhao, Z.Y., Zhang, K., Tian, C.Y., 2013. Reclamation and utilization of saline soils in arid Northwestern China: a promising halophyte drip-irrigation system. Environ. Sci. Technol. 47, 5518-5519.

Yu, R., Chen, D., 1999. The development and utilization of saline soil resources in China. Chin. J. Soil Sci. 30, 158-159.

Yuan, B.C., Xu, X.G., Li, Z.Z., Gao, T.P., Gao, M., Fan, X.W., Deng, H.M., 2007. Microbia biomass and activity in alkalized magnesic soils under arid conditions. Soil Biol. Biochem. 39, 3004-3013. 